\title{
平板の曲げ振動インテンシティのモード展開*
}

沼田 臨 ${ }^{* 1}$, 山崎 徹 ${ }^{* 2}$

\section{Modal Expansion of Structural Intensity for Flexural Vibration on Plates}

\author{
Nozomu NUMATA*1 $^{* 1}$ and Toru YAMAZAKI \\ ${ }^{* 1}$ Graduate school of Engineering, Kanagawa University \\ Rokkakubashi 3-27-1, Kanagawa-ku, Yokohama, 221-8686, Japan
}

This paper presents modal descriptions of structural intensity for flexural vibration on flat plate. The modal forms of the structural intensity are expressed by superposition of the product of weight coefficient and cross-modal function which can be estimated by two natural modes. The characteristics of the weight coefficients and the cross-modal functions are discussed by using numerical analysis. It is shown that the cross-modal functions can be classified into two types of distributions - power transmission and non power transmission types -. It is also shown that the non power transmission type cross-modal function can take no propagating power. At last we demonstrate that the derived modal form of the intensity can be useful to explain the difference of the structural intensity under two different excitation frequencies. The demonstration would suggest that the modal expansion can be effective for designing the structural intensity distribution.

Key Words : Structural Intensity, Modal Analysis, Method of Vibration Analysis, Computer Simulation, Vibration Control, Vibration of Continuous System

\section{1. はじめに}

「単位時間に単位幅を通過する振動エネルギー量」として定義される振動インテンシティ (Structural Intensity) は, 1970 年に Noiseux により提唱された ${ }^{(1)}$. その後, 振動インテンシティの近似值を実験的に測定する手法が, 1976 年に Pavić によって導かれた ${ }^{(2)}$. 振動インテンシティ（振動エネルギー流れ）を算出・測定することで，振 動エネルギーの伝播経路の解明, 加振源の位置の特定および入力パワーの評価, 部材間の伝達パワーの把握など が可能となる.

これまでの振動インテンシティの関連研究は，三種に大別できる. ひとつは振動インテンシティを構造診断に 用いる試み ${ }^{(3) \sim(8)}$ であり, もうひとつは様々な構造の振動インテンシティを測定・算出し構造変更による振動イン テンシティの変化を調べる研究(9) (11)であり, そして振動インテンシティを制御する方法の研究(12) (15)である. ま た，著者らは振動インテンシティを考慮したパッシブな低振動・低騒音構造設計手法の開発を目指して研究を行 っており ${ }^{(13)} \sim(15)$, そのためには, 低振動・低騒音な構造と振動インテンシティ分布の関係究明と, 振動インテン シティの制御法の確立という二つの課題の解決が必要と考えている.

そこで前報 ${ }^{(13)}$ では，パッシブな構造変更による振動インテンシティ制御の基礎研究として，はりの曲げ振動を 対象に任意の振動数における振動インテンシティのモード展開式を導出し, 振動インテンシティを各モード成分 に分離できることを示した. この展開式は, 振動変位の空間微分として表された振動インテンシティの定義式で

\footnotetext{
* 原稿受付 2011 年 4 月 22 日

*1 正員, 神奈川大学大学院 工学研究科 (广221-8686 神奈川県横浜市神奈川区六角橋 3-27-1)

*2 正員, 神奈川大学 工学部

E-mail:nozomu.numata@gmail.com
} 
表し，この定義式に振動変位のモード展開式を代入することで導出される．展開された各モード成分は分布を表 す「クロスモード関数」と，クロスモード関数の寄与度を表す「重み係数」の積として表現される．この展開式 により，振動インテンシティを固有モードに依存するクロスモード関数と加振情報に依存する重み係数に分離で きることを示した.

本報では, 対象を一様平板とし, まず振動インテンシティのモード展開式の導出と数值的な確認を行い, 次に 平板の振動インテンシティモード展開式における重み係数とクロスモード関数の特徴を考察し, 最後に振動イン テンシティを考慮した設計への試みとして, 振動インテンシティのモード展開式によって加振振動数の違いによ る振動インテンシティの変化を説明できることを示す. モード展開式の導出では, 平板の曲げ振動の振動インテ ンシティについてモード展開式を導出し, また, 損失係数微小かつ共振時に有効な近似式も導出する. 平板の振 動インテンシティのモード展開式の特徵の考察では, 重夕係数についてはりと同様に損失係数との関係を考察し, 共振時かつ損失係数微小の場合に近似が成り立つことを示し, クロスモード関数について分布形状と伝達パワー を考察し, 振動伝達パワーがゼロである非伝達型の分布が存在することを示す. その後, 二つの異なる加振振動 数の振動インテンシティの相違を, 振動インテンシティのモード展開式により説明し, 加振条件の変更によるパ ッシブな振動インテンシティ制御の可能性を示す.

\section{2. 平板の振動インテンシティのモード展開}

本章では, 振動インテンシティのモード展開式を導く.はじめに振動変位のモード展開式（モード変位式）を 示し, 次に振動インテンシティが振動変位の空間微分として表された定義式と振動インテンシティから振動伝達 パワーを算出する式を示し，最後に振動インテンシティのモード展開式を導出する.

\section{$2 \cdot 1$ モード変位式}

矩形平板上の点 $\left(x_{F} y_{F}\right)$ に振幅 $F$, 角振動数 $\omega$ の正弦加振力が作用寸るとき, 位置 $(x, y)$ における定常応答変位の

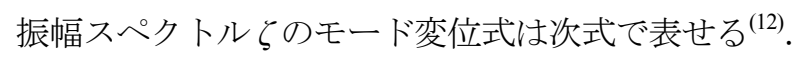

$$
\begin{gathered}
\zeta=\sum_{n=1}^{N} \alpha_{n} \phi_{n}(x, y) \\
\alpha_{n}=\frac{F \phi_{n}\left(x_{F}, y_{F}\right)}{\omega_{n}^{2}\left(1+j \eta_{n}\right)-\omega^{2}}
\end{gathered}
$$

ここで， $\alpha_{n}$ は重み係数， $N$ は考慮するモードの最高次数（採用モード数）, $\phi_{n}(x, y)$ は $n$ 次の正規モード（モ 一ド質量が 1 となる固有モードで，比例減衰を仮定しているため実固有モード）の点 $(x, y)$ の成分， $\omega_{n}$ と $\eta_{n}$ は $n$ 次の固有角振動数と損失係数, $j$ は虚数単位をそれぞれ表す.

\section{$2 \cdot 2$ 振動インテンシティ}

平板の曲げ振動の振動インテンシティは，単位幅あたりを単位時間に通過する振動エネルギーとして定義され $る^{(1)} . x y$ 面を板面とする一様平板において, 点 $(x, y)$ での振動インテンシティスペクトル $\mathbf{I}$ とその $x$ 軸方向成分 $I_{\mathrm{x}}$ は, 次式で表せる ${ }^{(1)}$.

$$
\begin{gathered}
\mathbf{I}=\left(I_{x}, I_{y}\right) \\
I_{x}=\frac{1}{2} \operatorname{Re}\left[-j \omega\left(Q_{x} \zeta^{*}+M_{y} \theta_{y}^{*}+M_{x y} \theta_{x}^{*}\right)\right]
\end{gathered}
$$




$$
\begin{gathered}
Q_{x}=D_{p}\left(\frac{\partial^{3} \zeta}{\partial x^{3}}+\frac{\partial^{3} \zeta}{\partial x \partial y^{2}}\right) \\
M_{y}=-D_{p}\left(\frac{\partial^{2} \zeta}{\partial x^{2}}+v \frac{\partial^{2} \zeta}{\partial y^{2}}\right) \\
M_{x y}=-(1-v) D_{p} \frac{\partial^{2} \zeta}{\partial x \partial y}
\end{gathered}
$$

ここで， $Q_{x}$ はせん断力， $M_{y}$ は曲げモーメント， $M_{x y}$ は㸚じりモーメント， $\theta_{x}$ は $x$ 軸まわりの角変位， $\theta_{y}$ は $y$ 軸ま わりの角変位, $D_{p}=E h_{p}{ }^{3} / 12\left(1-v^{2}\right)$ は板の曲げ剛性, $h_{p}$ は板厚, $v$ はポアソン比であり, 上付き * は複素共役 を表す. また，振動インテンシティの $y$ 軸方向成分 $I_{y}$ は式(4)から式(7)の $x$ と $y$ を入れ替え, 式(7)の符号を逆に することで求まる.

\section{$2 \cdot 3$ 振動伝達パワー}

振動インテンシティは単位幅あたりの伝達パワーである. 振動インテンシティに幅を掛けることで，伝達パワ 一が求まる. 図 1 のように, 振動インテンシティの $x$ 軸方向成分 $I_{x}$ が幅 $\Delta y_{i}$ を通過するとき, 伝達パワーの $x$ 軸 方向成分 $P_{x}$ は次式で表される.

$$
P_{x}=\sum_{i} I_{x i} \Delta y_{i}
$$

ここで $\Sigma \Delta y_{i}$ は $y$ 軸方向の板幅と等しく, 同様に, 伝達パワーの $y$ 軸方向成分 $P_{\mathrm{y}}$ については式(8)の $x$ と $y$ を入れ 替えることで求まる.

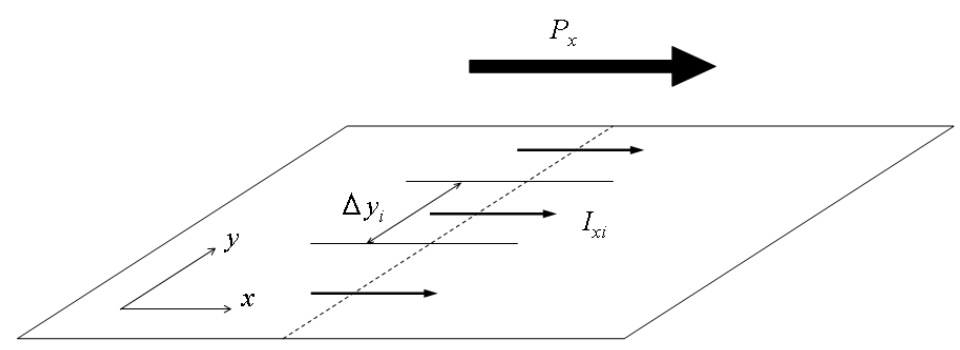

Fig.1 Structural intensity $I_{x}$ and transmitted power $P_{x}$

\section{$2 \cdot 4$ 振動インテンシティのモード展開式}

本節では振動インテンシティの二つのモード展開式を導出する. ひとつは任意の振動数で励振される場合の式 で，もうひとつは損失係数が微小かつ共振時に限った近似式である.

\section{$2 \cdot 4 \cdot 1$ 任意の振動数で励振される場合}

振動インテンシティのモード展開式は, 式(5)から式(7)に式(1)を代入することで, 式(4)から以下に得られる.

$$
\begin{gathered}
I_{x}=\sum_{m=1}^{N-1} \sum_{n=m+1}^{N} \beta_{m n} \Phi_{m n}^{x} \\
\beta_{m n}=\frac{\omega D_{p}}{2}\left(\operatorname{Re}\left[\alpha_{m}\right] \operatorname{Im}\left[\alpha_{n}\right]-\operatorname{Im}\left[\alpha_{m}\right] \operatorname{Re}\left[\alpha_{n}\right]\right)
\end{gathered}
$$




$$
\Phi_{m n}^{x}=\Phi_{m n}^{x s f}+\Phi_{m n}^{x b m}+\Phi_{m n}^{x \quad t m}
$$

ここで $\beta_{m n}$ は重み係数であり, 式(2)の $\alpha_{n}$ と式(10)より, 主として加振条件（加振力, 固有モードの加振点成分, 加振角振動数）に依存する.

$\Phi_{m n}^{x}$ はクロスモード関数の $x$ 軸方向成分で, せん断依存成分 $\Phi_{m n}^{x}{ }_{m}^{s f}$ と曲げモーメント依存成分 $\Phi^{x}{ }_{m n}^{b m}$, およびね

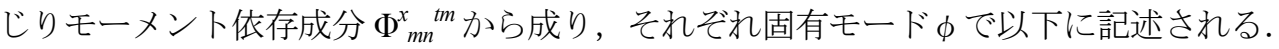

$$
\begin{gathered}
\Phi_{m n}^{x s f}=\phi_{m}\left(\frac{\partial^{3} \phi_{n}}{\partial x^{3}}+\frac{\partial^{3} \phi_{n}}{\partial x \partial y^{2}}\right)-\left(\frac{\partial^{3} \phi_{m}}{\partial x^{3}}+\frac{\partial^{3} \phi_{m}}{\partial x \partial y^{2}}\right) \phi_{n} \\
\Phi_{m n}^{x \quad b m}=-\frac{\partial \phi_{m}}{\partial x}\left(\frac{\partial^{2} \phi_{n}}{\partial x^{2}}+v \frac{\partial^{2} \phi_{n}}{\partial y^{2}}\right)+\left(\frac{\partial^{2} \phi_{m}}{\partial x^{2}}+v \frac{\partial^{2} \phi_{m}}{\partial y^{2}}\right) \frac{\partial \phi_{n}}{\partial x} \\
\Phi_{m n}^{x t m}=-(1-v) \frac{\partial \phi_{m}}{\partial y} \frac{\partial^{2} \phi_{n}}{\partial x \partial y}+(1-v) \frac{\partial^{2} \phi_{m}}{\partial x \partial y} \frac{\partial \phi_{n}}{\partial y}
\end{gathered}
$$

なお，クロスモード関数の $y$ 軸方向成分 $\Phi^{y}{ }_{m n}$ を求めるには式(12)から式(14)の $x$ と $y$ を入れ替え，式(14)の符号を 逆にすれば良い. 平板上の点 $(x, y)$ でのクロスモード関数 $\boldsymbol{\Phi}_{m n}$ は, 振動インテンシティと同様にベクトルであり, $x$ 軸方向成分 $\Phi_{m n}^{x}$ と $y$ 軸方向成分 $\Phi_{m n}^{y}$ を用いて $\boldsymbol{\Phi}_{m n}=\left(\Phi_{m n}^{x}, \Phi_{m n}^{y}\right)$ と表される.

式(12)から式(14)を見ると，クロスモード関数は固有モードに依存していることがわかる. すなわち，クロスモ 一ド関数は, 構造と境界条件に依存し加振条件によらない. また, 二つの共振次数 $m$ 次と $n$ 次の固有モードの空 間微分項を掛け合わせるため, クロスモード関数に直交性は成り立たない.

\section{$2 \cdot 4 \cdot 2$ 共振時の場合}

前報 ${ }^{(13)}$ で示したはりの場合と同様, 平板においても, 損失係数 $\eta_{n}$ が小さく共振時（加振角振動数が $r$ 次の固有 角振動数近傍）の場合，式(9)に示した振動インテンシティのモード展開式はより少ないモード数で近似でき，以 下で表せる。

$$
\begin{gathered}
I_{x} \approx \sum_{n=1}^{N} \beta_{r n} \Phi_{r n}^{x} \\
\beta_{r n}=-\frac{\omega D_{p}}{2} \operatorname{Im}\left[\alpha_{r}\right] \operatorname{Re}\left[\alpha_{n}\right]
\end{gathered}
$$

この近似は，式(10)で示したうち, $m=r$ である重み係数 $\beta_{m n}=\beta_{r n}$ と比べて，その他の $m \neq r$ である $\beta_{m n}$ が微小とな ることを利用している(12).

\section{3. 数値シミュレーションによるモード展開式の確認}

本章では第 2 章で示した二つの振動インテンシティのモード展開式（式(9)とその近似式である式(15)）につい て, 数值シミュレーションにより, まず加振条件に依存ずる重み係数, 次に固有モードに依存するクロスモード 関数の特徵を述べる. その後, クロスモード関数と重み係数を用いて振動インテンシティを求め, モード展開式 の確認を行う。

\section{$3 \cdot 1$ 対象構造物と検討条件}


対象構造物は $x y$ 平面を板面とする鋼製の周辺単純支持矩形平板 $\left(0.6 \mathrm{~m} \times 0.9 \mathrm{~m} \times 4.5 \mathrm{~mm}\right.$, 縦弾性係数 $2.0 \times 10^{11} \mathrm{~Pa}$, 密度 $\left.7834.6 \mathrm{~kg} / \mathrm{m}^{3}\right)$ である. 対象平板の固有角振動数 $\omega_{n}$ と正規固有モード $\phi_{n}$ はそれぞれ次式より求める.

$$
\begin{gathered}
\omega_{n}=\sqrt{\frac{D_{p}}{\rho h_{p}}}\left\{\left(\frac{p \pi}{a}\right)^{2}+\left(\frac{q \pi}{b}\right)^{2}\right\} \\
\phi_{n}(x, y)=\frac{2}{\sqrt{\rho a b h}} \sin \left(\frac{p \pi}{a} x\right) \sin \left(\frac{q \pi}{b} y\right)
\end{gathered}
$$

ここで, $p$ と $q$ は $x$ と $y$ 方向の腹の数, $a$ と $b$ はそれぞれ矩形平板の長辺と短辺の長さである.

加振は単点を正弦波加振するものとし. 加振力 $F=1 \mathrm{~N}$, 加振位置 $\left(x_{F}, y_{\mathrm{F}}\right)=(0.2 \mathrm{~m}, 0.2 \mathrm{~m})$, 加振角振動数を 844 $\mathrm{rad} / \mathrm{sec}$ (第 3 次固有角振動数, $r=3$ ), 損失係数 $\eta_{n}$ は 0.003 と 0.3 の 2 種, 採用モード数は $36(p=1 \sim 6, q=1 \sim 6)$ と する.

\section{$3 \cdot 2$ 重み係数の特徵}

対象平板の重み係数 $\beta_{m n}$ を式(10)より求めた結果を表 1 に示す. ここでは $m=1 \sim 3, n=1 \sim 5$ を示す. 表 1(a)は損 失係数 $\eta_{n}=0.003$, 表 1(b)は $\eta_{n}=0.3$ とした場合の結果である. 共振時かつ損失係数が小さい場合は表 1(a)のよう に太字で示した成分（第 3 次共振角振動数のため $m=r=3$ の行, $n=r=3$ の列）はその他の成分と比べ大きくな っている. 一方， $\eta_{n}=0.3$ である表 1(b)では，太字で示した成分はその他の成分と比べ顕著となっていない. すな わち，共振時かつ損失係数が小さい場合にのみ式(15)の近似式が成り立つことを意味している.

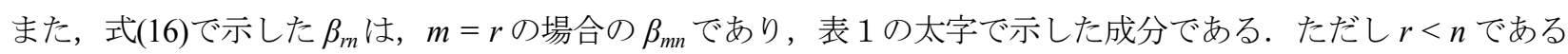
成分については式(10), 式(16)より $\beta_{n m}=-\beta_{m n}$ であるため太字で示した成分と符号が逆転する (例えば, $\beta_{31}=-\beta_{13}$, $\left.\beta_{32}=-\beta_{23}\right)$.

\section{$3 \cdot 3$ クロスモード関数の特徴}

対象平板のクロスモード関数 $\boldsymbol{\Phi}_{m n}$ の一部（ $\left.m=1 \sim 3, n=1 \sim 5\right)$ を式(11)より求めた結果を図 2 に示す. これらの クロスモード関数を縦方向および横方向の伝達パワー成分（式(8)の振動インテンシティ $I$ の代わりにクロスモー ド関数 $\mathbf{\Phi}$ を代入した, 伝達パワーのモード成分相当) で分類すると, 縦横ともに伝達パワー成分がゼロである非 伝達型クロスモード関数（図 2 の $\left.\boldsymbol{\Phi}_{15}, \boldsymbol{\Phi}_{23}, \boldsymbol{\Phi}_{34}\right)$ と，伝達パワー成分をもつパワー伝達型クロスモード関数（図 2 の $\boldsymbol{\Phi}_{12}, \boldsymbol{\Phi}_{14}, \boldsymbol{\Phi}_{25}$ など）に分類できる. それぞれのタイプのクロスモード関数の伝達パワー成分の例を図 3 に 示す. 今回の計算結果では, パワー伝達型クロスモード関数はすべて縦または横方向のどちら一方向への伝達パ ワーを持っていた．これらのクロスモード関数をそれぞれ自在に励起させることができれば，例えば縦方向の伝 達パワーを抑制するために横方向のみの伝達パワーをもつクロスモード関数と縦横の伝達パワーがゼロであるク ロスモード関数のみを励起させ，縦方向のエネルギー伝達を抑制することができると考えられる．また，複数の 平板で構成されるような構造物の一部を嫌振部として嫌振部への伝達を抑制するような場合は, ゼロでない伝達 パワーをもつクロスモード関数を利用し，嫌振部以外への伝達パワーを大きくすることで，結果として嫌振部へ のエネルギー伝達を抑制することができると考えられる.

また，共振時かつ損失係数が小さい場合の近似式(15)で用いる $\boldsymbol{\Phi}_{r n}$ は $r=m$ の場合の $\boldsymbol{\Phi}_{m n}$ を用いればよく $r<n$ である成分については $\beta_{r n}$ と同様に $\boldsymbol{\Phi}_{n m}=-\boldsymbol{\Phi}_{m n}$ であることを利用して求めることができる.

Table 1 Comparison of weight coefficients $\beta_{m n}$ of the plate with small and large loss factor $\left(\omega=\omega_{3}=844 \mathrm{rad} / \mathrm{sec}, N=36\right)$

\begin{tabular}{|c|c|c|c|c|c|c|}
\hline & \multicolumn{5}{|c|}{$n$} \\
\hline & & 1 & 2 & 3 & 4 & 5 \\
\hline \multirow{3}{*}{$m$} & 1 & 0 & $2.1 \times 10^{-10}$ & $8.0 \times 10^{-5}$ & $-1.2 \times 10^{-\mathrm{s}}$ & $93 \times 10^{-10}$ \\
\hline & 2 & 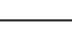 & 0 & $4.1 \times 10^{-5}$ & $-6.6 \times 10^{-9}$ & $5.7 \times 10^{-10}$ \\
\hline & 3 & 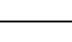 & - & 0 & $-2.4 \times 10^{-4}$ & $3.6 \times 10^{-5}$ \\
\hline
\end{tabular}

(a) $\eta_{n}=0.003$ (b) $\eta_{n}=0.3$ 


\section{$3 \cdot 4$ 振動インテンシティのモード展開式の確認}

数值シミュレーションによる振動インテンシティの算出結果を示し，モード展開式の確認を行う。確認は式(4) に示した厳密解を基準として，振動インテンシティ分布形状， $x$ 軸方向および $y$ 軸方向の伝達パワーの評価で行 う。二つのモード展開式から求めた振動インテンシティおよび伝達パワーの厳密解との比較結果を図 4 と図 5 に 示す. 図 4 は損失係数 $\eta_{n}=0.003$, 図 5 は $\eta_{n}=0.3$ の結果である. ベクトル図は振動インテンシティを, 棒グラフ は $x$ 軸方向の伝達パワー $P_{x}$ および $y$ 軸方向の伝達パワー $P_{y}$ を表寸. 各図の(a)が式(4)の定義式による厳密解, (b) が式(9)のモード展開式による解，(c)が式(15)の近似式による解である。また，近似式から求めた伝達パワーの相
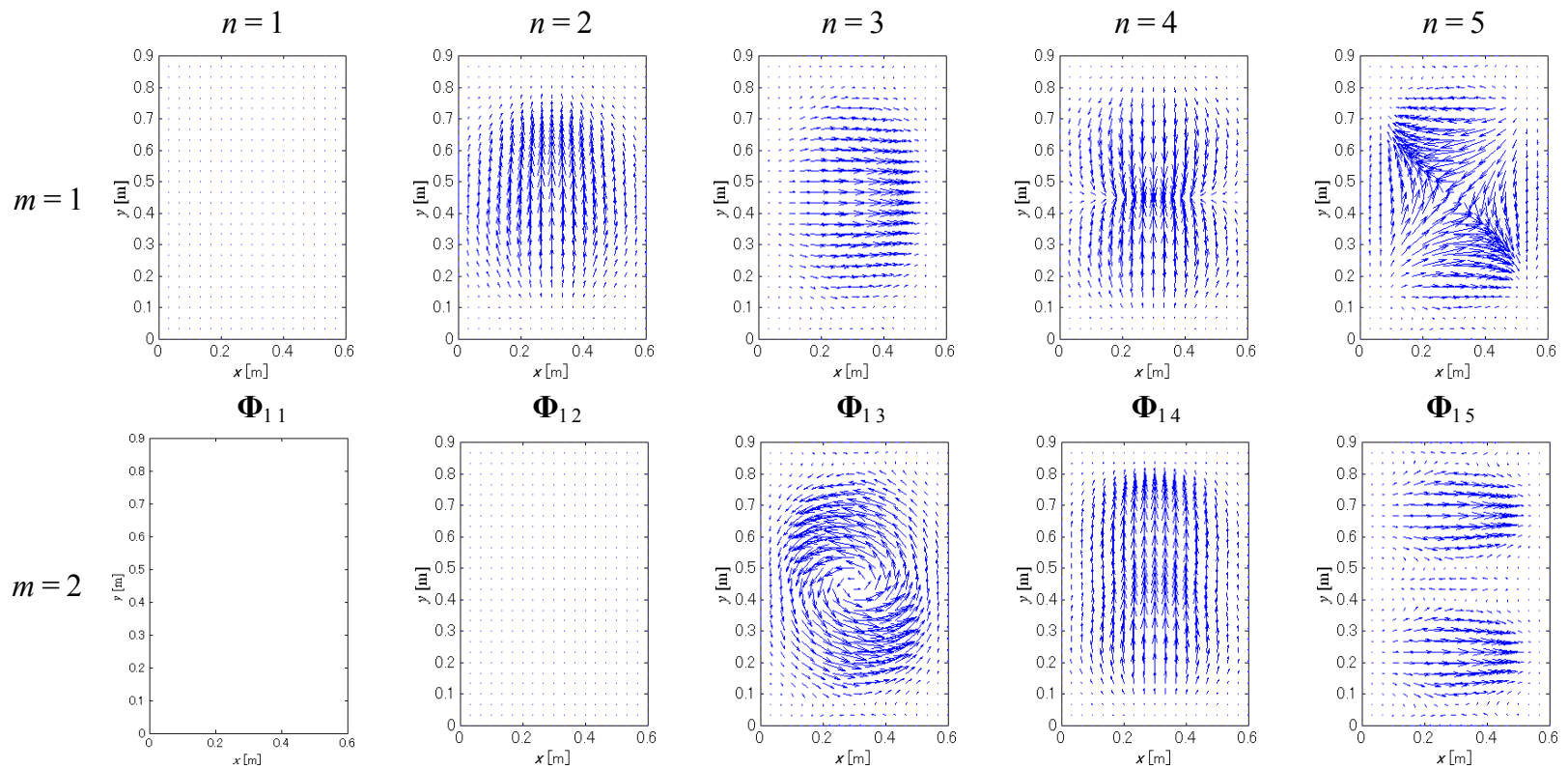

$\boldsymbol{\Phi}_{22}$
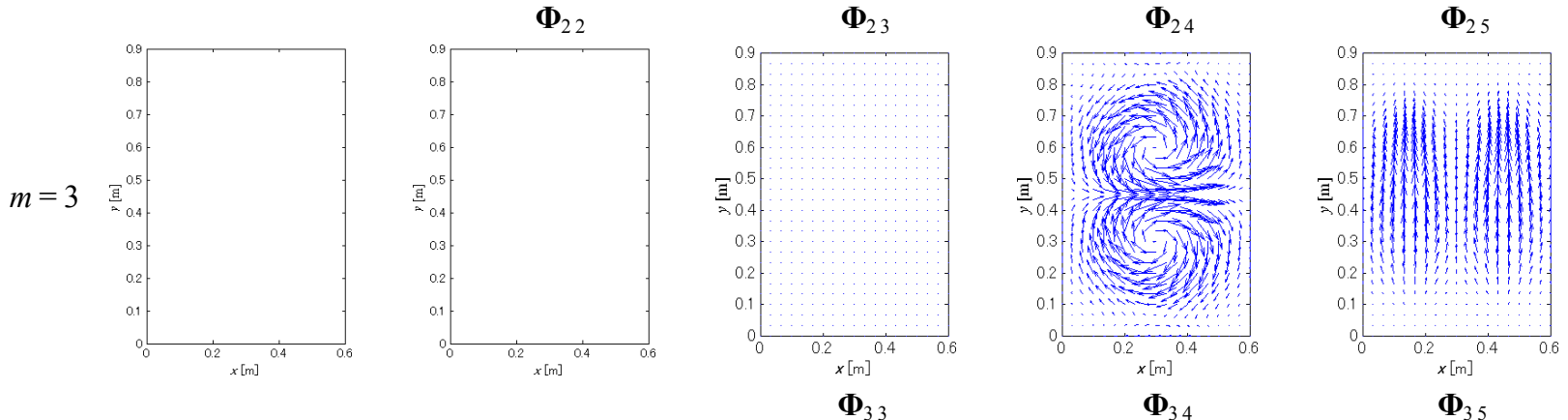

Fig.2 Examples of cross-modal functions $\boldsymbol{\Phi}_{m n}$ of the flat rectangular simple supported plate by Eq.(11) (with Eq.(9) under excitation of arbitary frequency)

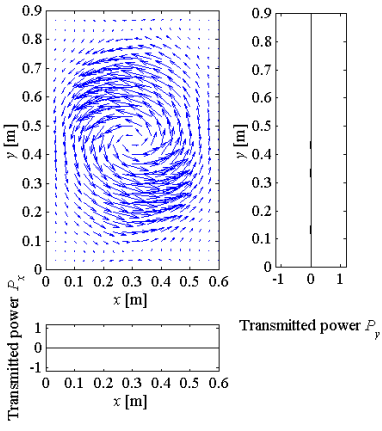

(a) Non power transmission type $\left(\boldsymbol{\Phi}_{23}\right)$

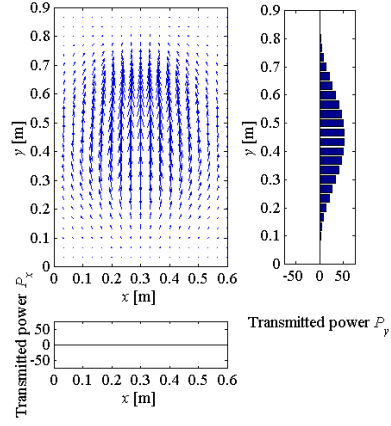

(b) Power transmission type $\left(\boldsymbol{\Phi}_{12}\right)$

Fig.3 Samples of two types of cross-modal functions 
対誤差を図 6 と図 7 に示す．なお，近似の無いモード展開式(9)による伝達パワーの相対誤差は $0 \%$ でることが 自明であるため省略する．また，加振位置などの不連続部近傍の振動インテンシティを正確に算出するためには 多数のモードを重㸚わせる必要がある ${ }^{(13)}$ が, 本報では不連続部近傍の振動インテンシティを精度良く求めるこ とが本義でないことと，この影響は本報で述べた三つの振動インテンシティ算出結果に等しく影響することから， モード重㸚合わせ数の不足から生じる誤差についてはここでは扱わない.

図 4 と図 6 より，損失係数が小さい場合 $\left(\eta_{n}=0.003\right)$, モード展開式(9) と近似式(15)はどちらも式(4)の厳密解 と等しい振動インテンシティを得られることがわかる。モード展開式による図 4(b)および近似式による図 4(c)の ベクトル図は厳密解による図 4(a) と等しく, 近似式(15)から求めた伝達パワーを厳密解と比較した図 6 より近似式 の相対誤差は $1 \%$ 未満である.

一方，図 5 と図 7 より，損失係数が大きい場合 $\left(\eta_{n}=0.3\right)$ は，モード展開式の結果には誤差がなく，近似式の 結果にのみ誤差が見られる。モード展開式(9)による図 5(b)の結果は厳密解による図 5(a)の結果と等しく, 伝達パ ワーの誤差も $1 \%$ 未満であるが, 近似式(15)による図 5(c)の結果は厳密解と比較して平板上部の渦巻きの中心位置 が紙面右方向へずれており，振動インテンシティベクトルの大きさも異なる. また，図 7 に示すように，伝達パ ワーの相対誤差も最大で $100 \%$ 程度となっている.

以上から, 第 2 章で導出したモード展開式(9)が厳密解と一致することと, 損失係数が小さく共振時であれば近 似式(15)も厳密解と一致することを確認できる.

\section{4. 振動インテンシティモード展開式の利用}

第 3 章で得た振動インテンシティのモード展開式に関する知見を用いて, 振動インテンシティの変化を考察す る. 一般に, 固有值解析により固有モードを求めると, 振動応答を考える足がかりとなる. 同様に, 振動インテ ンシティのモード展開式によりクロスモード関数を求めると，振動インテンシティを考える足がかりとなる. 例 えば，加振条件の変更により特定のクロスモード関数の影響を変更することで，振動インテンシティを制御する ことが考えられる.

そこで本章では，モード展開式を用いて振動インテンシティを制御する可能性を示すために，加振角振動数の 違いによる振動インテンシティ分布の変化を, 振動インテンシティモード展開式で説明できることを示す. 具体 的には, まず二つの加振角振動数に関して振動インテンシティ分布を求め, その後両分布の違いをモード展開式 の観点から説明する. 構造物と加振条件は第 3 章と同じ, 損失係数は $\eta_{n}=0.003$ の一定, 加振位置 $\left(x_{F}, y_{\mathrm{F}}\right)=(0.2 \mathrm{~m}$, $0.3 \mathrm{~m}$ ）として, 加振角振動数が $\omega=274 \mathrm{rad} / \mathrm{s}$ （第 1 次固有角振動数， $r=1 ）$ と $\omega=528 \mathrm{rad} / \mathrm{s}$ （第 2 次固有角振動 数， $r=2 ）$ の二条件であるとき, 加振角振動数の違いによる相違を解説する. このとき, 構造物が変わらないた め, クロスモード関数は第 3 章と同じく一定であり, 重み係数のみが変化する. なお, 共振時かつ損失係数が小 さいため，検討には近似式(15)を用いる.

$\omega=274 \mathrm{rad} / \mathrm{s}(r=1)$ の場合と $\omega=528 \mathrm{rad} / \mathrm{s}(r=2)$ の場合について, 重み係数の一部を図 8 に, クロスモード関数 の一部を図 9 に, 振動インテンシティと伝達パワーを図 10 に示寸. $\omega=274 \mathrm{rad} / \mathrm{s}(r=1)$ の場合の重み係数 $\beta_{1 m}$ を図 $8(\mathrm{a})$ で見ると， $\beta_{12}, \beta_{13}, \beta_{15}$ が支配的である. このとき，振動インテンシティ分布を構成する主なクロスモード関 数は $\boldsymbol{\Phi}_{12}, \boldsymbol{\Phi}_{13}, \boldsymbol{\Phi}_{15}$ である. 図 9 で $\boldsymbol{\Phi}_{12}, \boldsymbol{\Phi}_{13}, \boldsymbol{\Phi}_{15}$ の流れを確認し, 図 10(a)の振動インテンシティ分布を見ると, 全体としては右上方向へ流れる分布形状であり, 板面左下部では $\boldsymbol{\Phi}_{15}$ により板面左下方向へと流れる分布形状で あることが見てとれる. 一方， $\omega=528 \mathrm{rad} / \mathrm{s}(r=2)$ の場合の重み係数は図 $8(\mathrm{~b})$ より $\beta_{21}, \beta_{23}, \beta_{25}$, が支配的である ため, このとき振動インテンシティ分布を構成する主なクロスモード関数は $\boldsymbol{\Phi}_{21}, \boldsymbol{\Phi}_{23}, \boldsymbol{\Phi}_{25}$ である. また, $\beta_{21}<0$ であるため, $\boldsymbol{\Phi}_{21}$ については図 9 の $\boldsymbol{\Phi}_{21}$ と逆方向の流れになる. $r=1$ の場合と同様にして図 10(b)の振動インテ ンシティ分布を見ると, 板面下部では $\boldsymbol{\Phi}_{23}$ と $\boldsymbol{\Phi}_{25}$ により右方向への流れ, 板面上部では $\boldsymbol{\Phi}_{23}$ と $\boldsymbol{\Phi}_{25}$ が打ち消しあ い, $\boldsymbol{\Phi}_{21}$ の逆方向である上方向の流れが見て取れる.

以上より, $\omega=274 \mathrm{rad} / \mathrm{s}(r=1)$ と $\omega=528 \mathrm{rad} / \mathrm{s}(r=2)$ の二の場合を比較すると, 図 10(a) と図 10(b)の分布の違 いは $\boldsymbol{\Phi}_{15}$ と $\boldsymbol{\Phi}_{23}$ の違いであると考えられる。これは， $\omega=274 \mathrm{rad} / \mathrm{s}$ では $\boldsymbol{\Phi}_{12}, \boldsymbol{\Phi}_{13}, \boldsymbol{\Phi}_{15}$ が支配的, $\omega=528 \mathrm{rad} / \mathrm{s}$ で は $\boldsymbol{\Phi}_{21}, \boldsymbol{\Phi}_{23}, \boldsymbol{\Phi}_{15}$ が支配的であり, 式(11)より $\boldsymbol{\Phi}_{12}=-\boldsymbol{\Phi}_{21}$ であることと, 図 8 より $\boldsymbol{\Phi}_{13}$ と $\boldsymbol{\Phi}_{25}$ が概ね同様の分布 


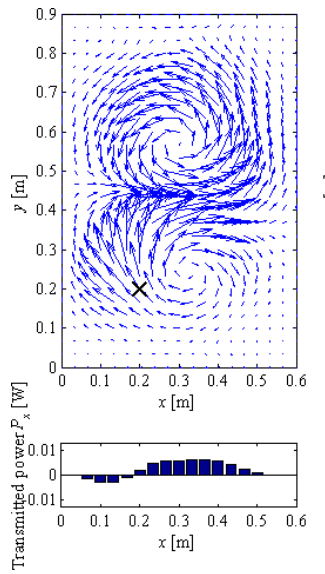

(a) Exact result by Eq.(4)

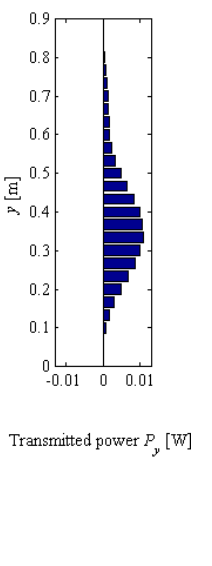

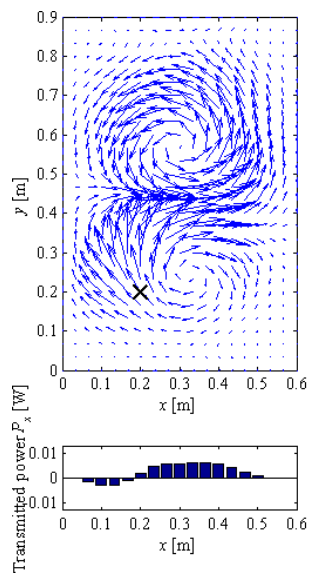

(b) Modal expansion by Eq.(9)

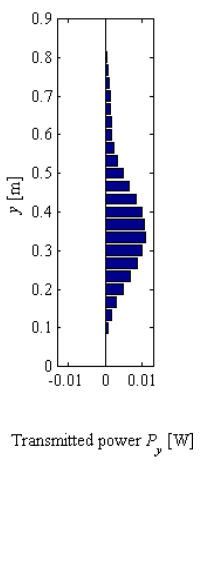

(c) Approximation at resonance by Eq.(15)

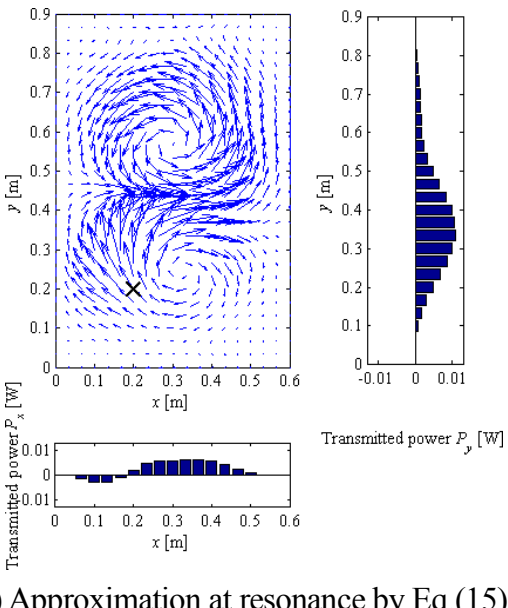

Fig.4 Comparison of structural intensities and transmitted powers by each solutions in case of small loss factor $\left(\omega=\omega_{3}=844 \mathrm{rad} / \mathrm{sec}, \eta_{m n}=0.003, N=36\right)$

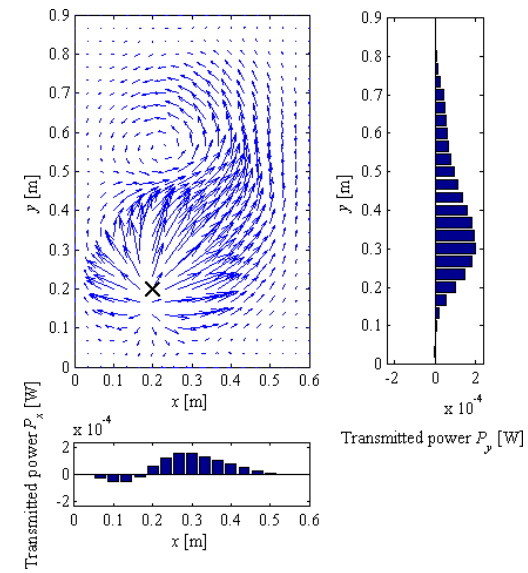

(a) Exact result by Eq.(4)

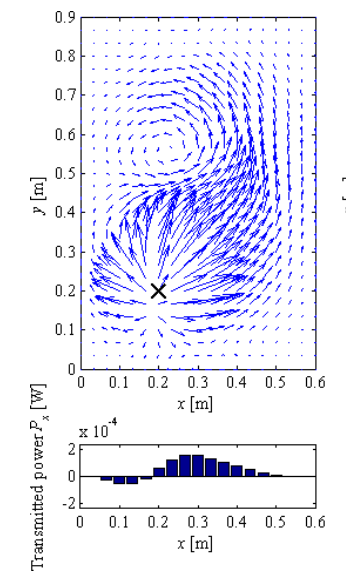

(b) Modal expansion by Eq.(9)

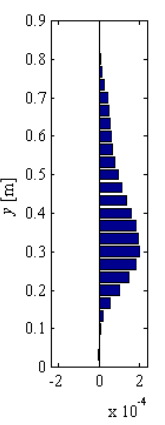

Transmitted power $P_{y}[\mathrm{~W}]$
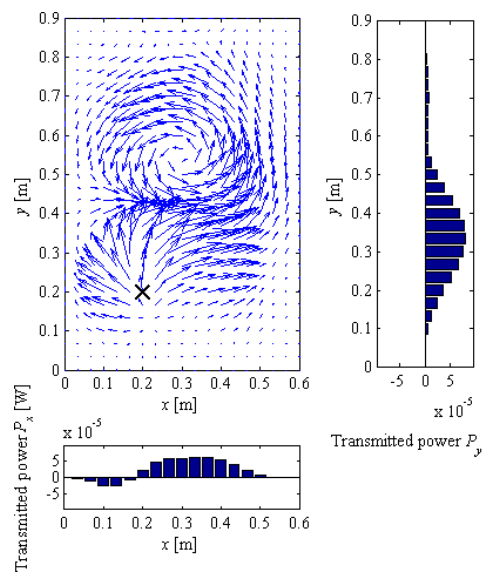

Transmitted power $P_{y}[\mathrm{~W}]$

Fig.5 Comparison of structural intensities and transmitted powers by each solutions in case of large loss factor $\left(\omega=\omega_{3}=844 \mathrm{rad} / \mathrm{sec}, \eta_{m n}=0.3, N=36\right)$

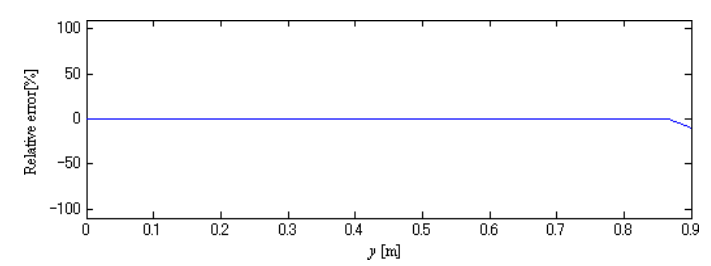

(a) Error between the powers flowing along y-axis

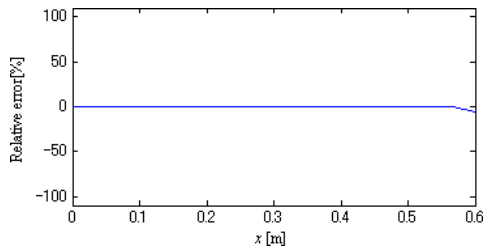

(b) Error between the powers flowing along x-axis

Fig.6 Relative errors between exact result of Eq.(4) and approximation at resonace by Eq.(15) in case of small loss factor $\left(r=3, \omega=\omega_{3}=844 \mathrm{rad} / \mathrm{sec}, \eta_{m n}=000.3, N=36\right)$

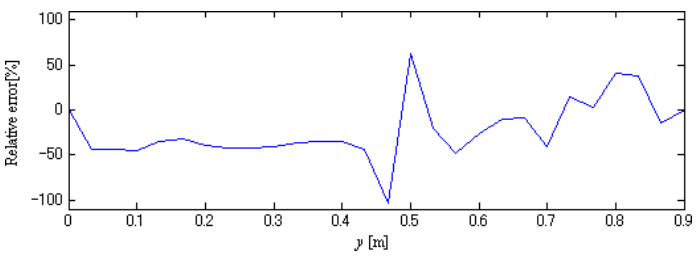

(a) Error between the powers flowing along y-axis

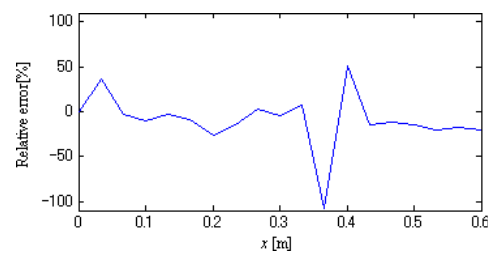

(b) Error between the powers flowing along $\mathrm{x}$-axis

Fig.7 Relative errors between exact result of Eq.(4) and approximation at resonace by Eq.(15) in case of large loss factor

$$
\left(r=3, \omega=\omega_{3}=844 \mathrm{rad} / \mathrm{sec}, \eta_{m n}=0.3, N=36\right)
$$




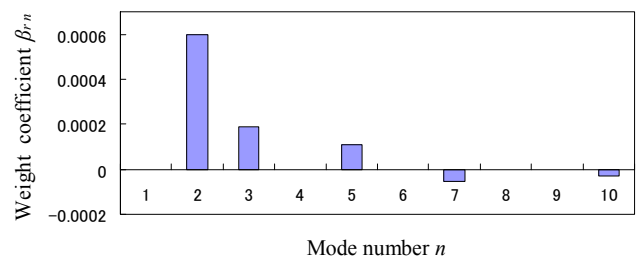

(a) $1 \mathrm{st}$ resonance $(r=1, \omega=274 \mathrm{rad} / \mathrm{sec})$

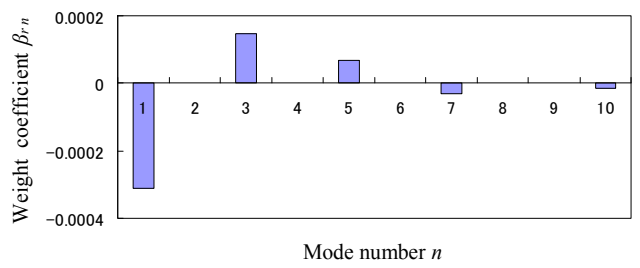

(b) 2nd resonance $(r=2, \omega=528 \mathrm{rad} / \mathrm{sec})$

Fig.8 Examples of weight coefficients $\beta_{r n}$ of the plate in case of small loss factor by Eq.(16)
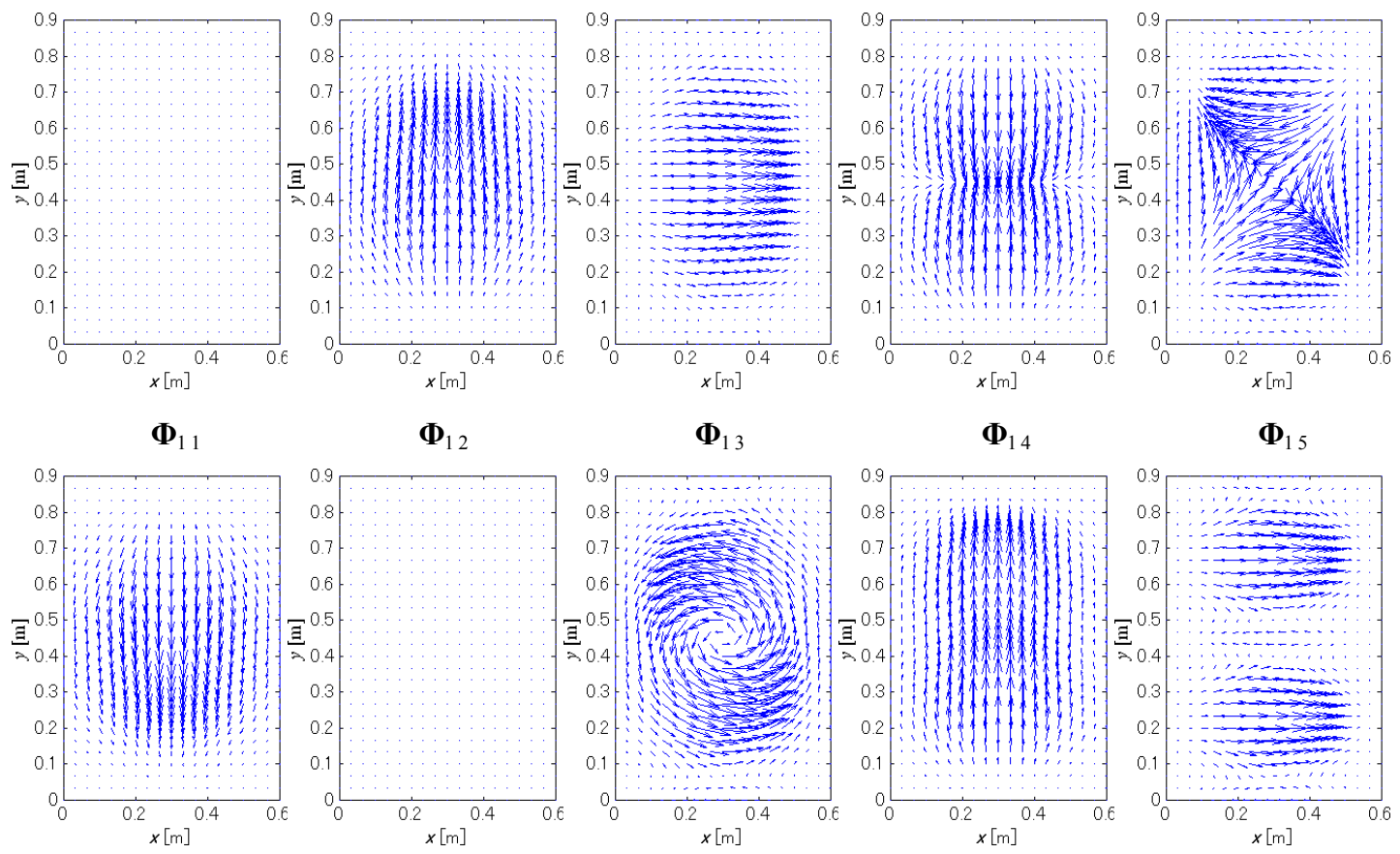

$\boldsymbol{\Phi}_{21}$

$\boldsymbol{\Phi}_{22}$

$\boldsymbol{\Phi}_{23}$

$\boldsymbol{\Phi}_{24}$

$\boldsymbol{\Phi}_{25}$

Fig.9 Examples of cross-modal functions of the plate for eq.(15) $(r=1,2)$

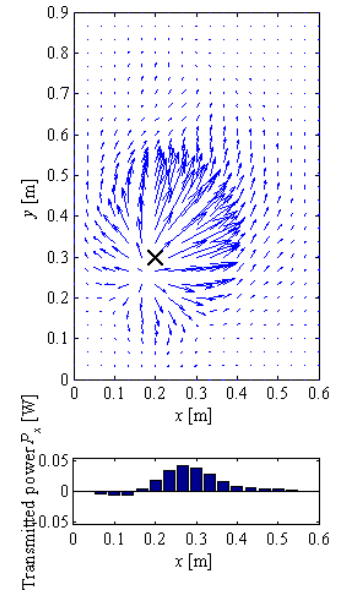

(a) 1 st resonance $(r=1, \omega=274 \mathrm{rad} / \mathrm{sec})$

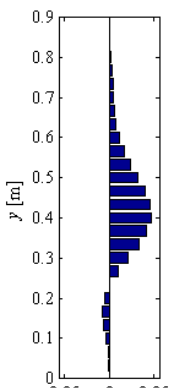

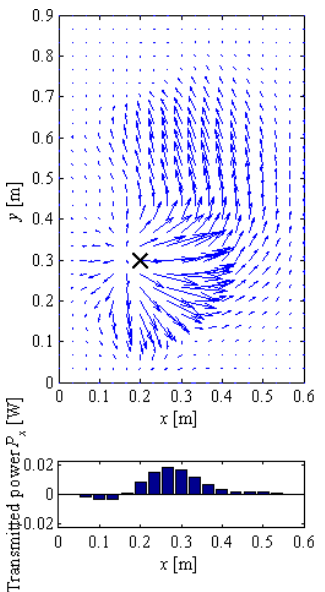

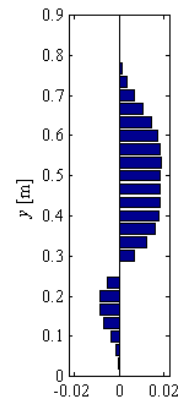

Transmitted power $P_{y}[\mathrm{~W}]$

(b) 2nd resonance $(r=2, \omega=528 \mathrm{rad} / \mathrm{sec})$

Fig.10 Comparison between structural intensy under excitation at 1 st and 2 nd resonance frequency by Eq. $(15)\left(\eta_{m n}=0.003, N=36\right)$ 
であることを考慮した結果である. 図 10 の二つの分布は, どちらもまず上方向 $\left(\boldsymbol{\Phi}_{12}\right.$ と一 $\left.\boldsymbol{\Phi}_{21}\right)$ および右方向 $\left(\boldsymbol{\Phi}_{13}\right.$ と $\left.\boldsymbol{\Phi}_{25}\right)$ への流れがあり，そこに $\boldsymbol{\Phi}_{15}$ と $\boldsymbol{\Phi}_{23}$ がそれぞれ加わった形であると考えられる.

このように，本章では加振条件の違いによる振動インテンシティの分布形状の相違を，振動インテンシティの モード展開式で説明できることを示した．この考え方を発展させ，加振位置や加振周波数の変更により重み係数 を変更し, 特定の傾向をもつクロスモード関数（例えば $\boldsymbol{\Phi}_{15}$ や $\boldsymbol{\Phi}_{23}$ のような伝達パワーを抑制する非伝達型分布） を励起させる方法を確立すれば，振動インテンシティの制御が可能になると考えられる．また，複雑な形状の構 造物など, 非伝達型のクロスモード関数が存在しない場合は，特定方向の伝達パワーに注目し，嫌振部一の伝達 パワーを抑制するようなクロスモード関数を励起させることで, 平板と同様に振動インテンシティを考慮した伝 達パワー抑制が実現できると考えられる。

\section{5. おわりに}

振動インテンシティを考慮した機械構造物の低振動・低騒音化設計手法の開発を目指した本研究において, 本 報では平板の曲げ振動に注目し，振動インテンシティのモード展開式を導出した，成果は次の通り。

(1) 任意の振動数における平板の曲げ振動を対象に, 振動インテンシティのモード展開式を導出した. 展開式 は，二つの固有モードによって定まるクロスモード関数と，加振条件によって定まる重み係数の積の重 ね合わせとして表せる，また，損失係数が小さい場合，共振時に注目することでモード展開式を近似で き，振動インテンシティをより少ない重㸚合わせ数で表せることを示した．これは，損失係数が小さく かつ共振時であれば，各モード成分のうち共振次数を含まないモード成分の重み係数が，共振次数を含 むモード成分の重み係数と比較して微小となる性質を利用した近似である.

(2) クロスモード関数と重み係数の特徴を考察した. その結果, 平板のクロスモード関数は, はりでは得られ ない伝達パワーのない分布形状を含むことがわかった.この伝達パワーのない非伝達型のクロスモード 関数を励起させることができれば，振動インテンシティの制御による伝達パワーの抑制が可能になると 考えられる.

（3）モード展開式の妥当性を数值シミュレーションで確認した. モード展開式による解を振動インテンシティ の定義式による解と比較し，振動インテンシティの分布形状と伝達パワーが一致することを確認した.

(4) 加振条件を変更する場合の振動インテンシティ分布の変化について, モード展開式を用いて説明できるこ とを示した.

\section{謝 辞}

本研究は科研費 (基盤研究 (C) 21560251) の助成を受けて行われたものであり，ここに謝意を表す.

\section{文献}

(1) Noiseux, D.U., "Measurement of Power Flow in Uniform Beams and Plate," Journal of Acoustical Society of America, Vol.47 (1970), pp.238-247

(2) Pavic, G., "Measurement of structure borne wave intensity Part I : formulation of the methods," Journal of Sound and Vibration, Vol.49 No.2 (1976), pp.221-230

(3) 林卓郎, 江波戸明彦,“振動インテンシティを用いた地中漏水源の探査法”，日本機械学会論文集 C 編, Vol.66, No.652 (2000), pp.3849-3854

（4）東明彦, 水口文洋, “309 振動インテンシティによる板厚の予測可能性に関する研究”, 日本機械学会論文集 C 編, Vol.71, No.704 (2005), pp.1177-1184

(5) Li, T.Y., Zhang, T., Liu, J.X., and Zhang, W.H., "Vibrational wave analysis of infinite damaged beams using structure-borne power flow," Applied Acoustics, Vol.65 No.1 (2004), pp.91-100

(6) Zhu, X., Li, T.Y., Zhao, Y., and Liu, J.X., "Structural power flow analysis of Timoshenko beam with an open crack", Journal of Sound and Vibration, Vol.297, No.1-2 (2006), pp.215-226 
(7) Lee, H.P., Zhang, T., Liu, J.X., and Zhang, W.H., "Diversion of energy flow near crack tips of a vibrating plate using the structural intensity technique", Journal of Sound and Vibration, Vol.296, No.3 (2006), pp.602-622

(8) 本多 聡志, 長松 昭男, 鈴木 英男, “振動インテンシティによる動吸振器の効果”, 日本機械学会論文集 C 編, Vol.60, No.574 (1994), pp.1933-1940

(9) Xu, X.D., Lee, H.P., and Lu, C., "Power flow on paths in stiffened plates", Journal of Sound and Vibration, Vol.282, No.3-5 (2005), pp.1264-1272

(10) Cho, Dae-Seung, Kim Kyung-Soo, and Kim Byung-Hwa, "Structural intensity analysis of a large container carrier under harmonic excitations of propulsion system”, International Journal of Naval Architecture and Ocean Engineering, Vol.2, No 2 (2010), pp.87-95

(11) Liu, Z.S., Lee, H.P., and Lu, C., "Passive and active interior noise control of box structures using the structural intensity method", Applied Acoustics, Vol.67, No.2 (2005), pp.1264-1272

(12) 田中信雄，菊島義弘，黒田雅治，“薄肉平板のパワーフロー制御に関する研究”，日本機械学会論文集 C 編，Vol.58, No.556 (1992), pp.144-151

(13) 山崎徹,“はりの曲げ振動インテンシティのモード展開”, 日本機械学会論文集 C 編, Vol.73, No.731 (2007), pp.40-46

(14) 山崎徹,“振動インテンシティを用いた構造設計の基礎的検討”, 自動車技術, Vol.63, No.7 (2009), pp.91-97

(15) Numata, N., Yamazaki, T., "Determination of A Force Applying Position on plate for realizing Vortex-type Structural Intensity", Proceedings of 17th ICSV (2010), Cairo, 286.pdf 